\title{
Implementation of teleHealth using SKEDit for protein diet education for diabetes patients
}

\author{
Khoirul Rista Abidin¹, Eka Riana² \\ 1 Prodi Teknologi Laboratorium Medis, Politeknik Aisyiyah Pontianak, Indonesia \\ 2 Prodi Kebidanan, Politeknik Aisyiyah Pontianak, Indonesia
}

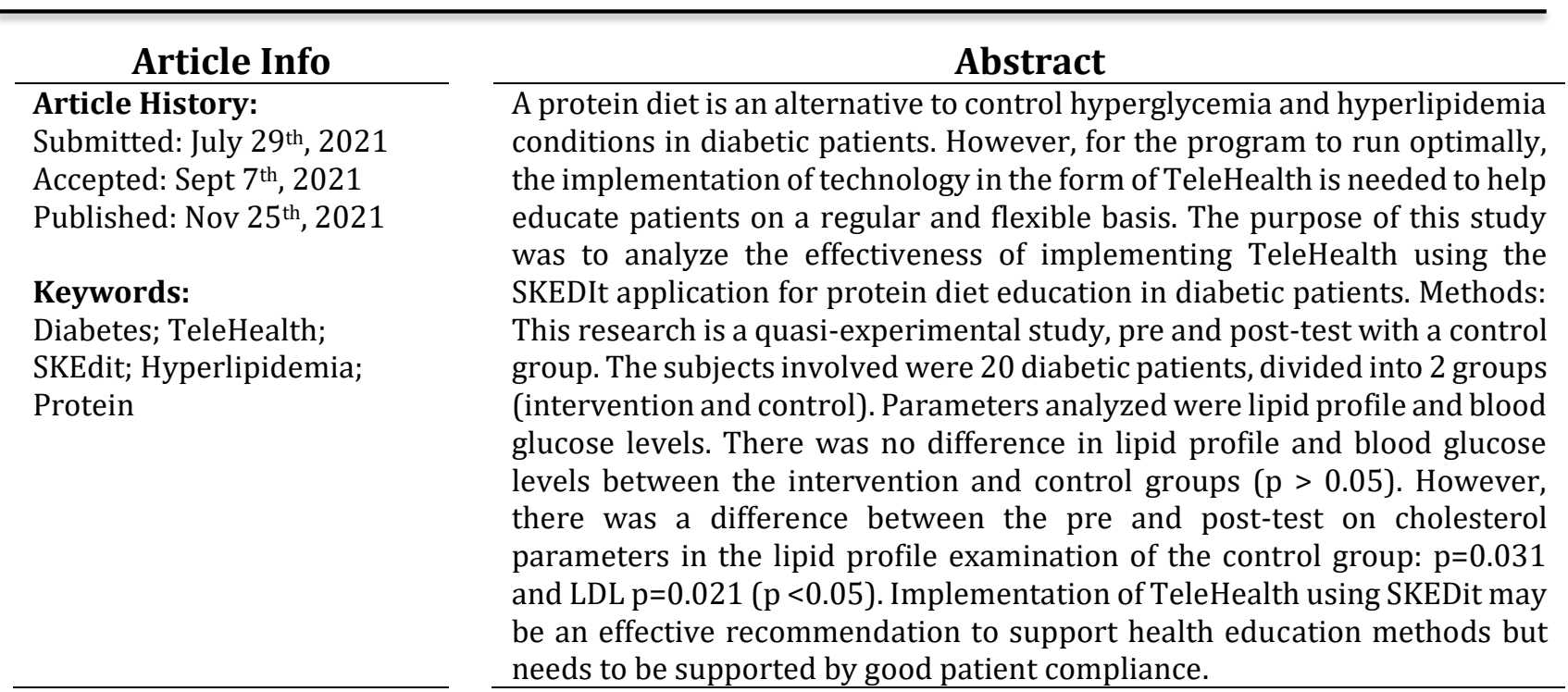

\section{PENDAHULUAN}

Diabetes termasuk ke dalam masalah kesehatan dengan jumlah kasus terbanyak di seluruh dunia. Studi menjelaskan bahwa pada tahun 2019 secara global terdapat sekitar 463 juta orang dewasa usia 20-79 tahun hidup dengan diabetes [1]. Prevalensi kasus diabetes diprediksi akan terus meningkat hingga mencapai 700 juta kasus di tahun 2045 [1]. Sama halnya dengan kondisi global, prevalensi diabetes di Indonesia juga termasuk tinggi. Indonesia menempati peringkat ke 7 dunia dengan kasus sebanyak 10 juta orang dewasa pada tahun 2015 [2].

Sebagian besar pasien diabetes menderita komplikasi kronis yang dapat menurunkan kualitas hidup. Umumnya komplikasi yang dialami dibagi menjadi 2 jenis : vaskuler dan non vaskuler [3]. Komplikasi vaskuler diklasifikasikan menjadi 2 tipe : mikrovaskular dan makrovaskuler. Keduanya menjadi penyebab terbesar kasus kematian terutama pada diabetes tipe 2 [4]. Studi epidemologi menjelaskan bahwa penderita diabetes dengan komplikasi makrovaskuler tertinggi terdapat pada

Corresponding author:

Khoirul Rista Abidin

khoirulrista@polita.ac.id

Media Keperawatan Indonesia, Vol 4 No 4, November 2021

e-ISSN: 2615-1669

ISSN: 2722-2802

DOI: $10.26714 / \mathrm{mki} .4 .4 .2021 .277-284$ 
benua Eropa. Sedangkan di Benua Asia, mayoritas kasus komplikasi adalah jenis mikrovaskuler [4]. Komplikasi mikrovaskuler dapat menjadi pemicu komplikasi lanjutan lain seperti retinopati, nefropati, neuropati dan gangguan penyembuhan luka pada kaki (diabatic foot ulcer) $[5,6]$.

Munculnya penyakit diabetes dapat disebabkan oleh banyak faktor yang menyebabkan hormon insulin mengalami penurunan fungsi bahkan jumlah produksi [7]. Ketika insulin mengalami masalah maka sel di tubuh akan mencari alternatif energi membentuk glukosa baru melalui pemecahan adiposit [8]. Kurangnya jumlah jaringan adiposa kemudian akan memicu peningkatan glukosa darah (hiperglikemia) serta kenaikan profil lipid (hiperlipidemia) [9]. Kebiasaan konsumsi makanan tinggi lemak dan obesitas juga turut berkontribusi memperparah kondisi hiperglikemia dan hiperlipidemia $[9,10]$.

Untuk mengendalikan keseimbangan profil lipid dan glukosa darah, dibutuhkan upaya preventif dan kuratif salah satunya dengan mengatur program diet [11]. Konsumsi makanan tinggi protein rendah karbohidrat bisa menjadi alternatif karena produksi energi dalam sel akan diperoleh dari metabolisme asam amino dalam reaksi glukoneogenesis [12]. Selain itu, program diet tersebut juga diprediksi mampu mencegah pembentukan baru dan pemecahan adiposit putih $[13,14]$. Dalam studi meta analisis dijelaskan bahwa risiko komplikasi kardiovaskuler akan terkendali karena kadar trigliserida profil lipid pada pasien diabetes mellitus tipe 2 berkurang [15]. Meskipun diet tinggi protein memberikan hasil yang bermanfaat, tidak semua orang mengaplikasikan program tersebut karena makanan tinggi lemak masih menjadi pilihan favorit [10]. Kurangnya terpapar informasi secara rutin juga dapat menjadi penyebab pasien diabetes belum mengaplikasikan program diet protein selama pemulihan. Agar dapat mencukupi kebutuhan protein harian, pasien diabetes dianjurkan untuk konsumsi protein sebanyak 0,8 - $1 \mathrm{~g}$ per $\mathrm{kg}$ berat badan per hari [16]. Sementara pasien dengan luka diabetes kronis mengkonsumsi protein minimal 1.25 - $1.5 \mathrm{~g}$ per kg berat badan per hari [17].

Putih telur termasuk ke dalam salah satu sumber protein yang mudah diperoleh. Dalam kajian studi klinis, konsumsi telur minimal 2 butir per hari berpotensi memperbaiki masalah resistensi insulin dan kadar profil lipid pada pasien diabetes melitus tipe 2 [18]. Putih telur menjadi bagian yang paling banyak mengandung nutrisi bermanfaat seperti protease, alkalase, thermolysin dan pepsin. Kelompok nutrisi tersebut dapat mengurangi plasma glukosa, menekan kadar triagliserol, meningkatkan produksi dan sensitifitas hormon insulin [18].

Edukasi tentang manfaat protein perlu dilakukan secara berkelanjutan kepada pasien diabetes agar dapat mendukung proses penyembuhan. Pada era digital yang saat ini sedang berkembang, teknologi smartphone melalui implementasi aplikasi dapat dimanfaatkan untuk menciptakan solusi yang inovatif. Edukasi kesehatan kepada pasien melalui media online atau sering dikenal dengan Telehealth memberikan efisiensi dalam mengendalikan penyakit kronis. Selain itu metode tersebut juga akan memudahkan pasien untuk belajar dan mendapatkan informasi kesehatan secara reguler [19]. Aplikasi SKEDit dengan fitur pengirim pesan otomatis menjadi rekomendasi yang bisa digunakan sehingga dapat membantu kelancaran proses edukasi kesehatan kepada pasien. Pada studi yang pernah dilakukan, aplikasi SKEDit memberikan dampak yang signifikan dalam mengedukasi keluarga pasien untuk patuh terhadap pengobatan talasemia [20]. Aplikasi SKEDit dapat dikombinasikan dengan Whatsapp sehingga mudah diimplementasikan bagi pengguna baru. 
Berdasarkan kajian studi di atas, edukasi pasien diabetes dalam melaksanakan program diet protein diharapkan dapat didukung melalui implementasi teknologi seperti aplikasi SKEDit. Maka dalam hal ini peneliti melakukan studi efektifitas penerapan SKEDit sebagai sarana edukasi diet protein pada pasien diabetes.

\section{METODE}

Penelitian ini merupakan studi kuasi eksperimen, pre dan post test dengan grup kontrol. Populasi studi adalah pasien rawat jalan dan inap yang didiagnosa diabetes mellitus tipe 2 oleh dokter di Klinik PKU Muhammadiyah Kitamura berdasarkan riwayat hasil pemeriksaan kadar glukosa darah lebih dari batas normal (HbAc $>7.0$ mmol atau > $200 \mathrm{mg} / \mathrm{dL}$ ). Namun penyampaian informasi tidak dilakukan berulang setiap hari.

Teknik pengambilan sampel dilakukan dengan metode purposive sampling. Variabel yang dianalisa dalam penelitian ini adalah kadar profil lipid (HDL, LDL, Kolesterol, Trigliserida) dan kadar glukosa darah. Kelompok penelitian dibagi menjadi 2. Kelompok intervensi adalah kelompok yang menerima informasi melalui aplikasi SKEDit dan Whatsapp dilakukan setiap hari selama 90 hari. Informasi yang dikirimkan pada kelompok intervensi berupa poster edukasi tentang manfaat konsumsi putih telur minimal 2 butir per hari bagi penderita diabetes. Aplikasi SKEDit dijalankan pada perangkat smartphone yang dilengkapi prosesor jenis Qualcom Snapdragon 720G Octa-core, model CPH2113 dan sistem operasi Android versi 11. Pada kelompok kontrol tidak diberikan informasi rutin tentang manfaat konsumsi putih telur melalui SKEDit maupun Whatsapp. Dengan demikian tidak ada informasi reguler yang mengingatkan tentang manfaat putih telur pada kelompok kontrol. Hanya pasien yang memiliki smartphone dan aplikasi yang dimasukkan ke dalam kelompok intervensi. Hal tersebut untuk memudahkan penyampaian informasi secara online.
Studi ini telah mendapatkan izin penelitian dari komite etik dengan nomor : 1734/KEPUNISA/XI/2020. Pasien yang dilibatkan telah mendapatkan edukasi tentang manfaat putih telur dari petugas kesehatan di Klinik pada saat kunjungan pertama.

Subjek penelitian yang diikutsertakan diminta untuk mengisi lembar persetujuan (informed consent). Pada saat pengumpulan subjek, peneliti mengumpulkan 43 orang. Namun pada akhir penelitian hanya 20 orang yang berhasil dilakukan post test karena sebagian sudah tidak melanjutkan perawatan di klinik. Dengan demikian data akhir yang dapat dianalisa adalah 10 orang untuk setiap kelompok.

Data karakteristik responden dianalisa menggunakan metode mann whitney. Untuk menganalisa perbedaan hasil akhir antara kelompok intervensi dan kontrol dilakukan dengan uji $t$ independen (independent-t test). Selain itu, pada studi ini juga dilakukan uji perbedaan antara hasil pemeriksaan awal dan akhir menggunakan uji t berpasangan (paired $t$ test).

\section{HASIL \\ Karakteristik Responden}

Karakteristik demografis responden penelitian dari subjek meliputi : jenis kelamin, usia, tingkat pendidikan, persentase lemak yang dikonsumsi, perkiraan porsi dalam sepiring sekali makan, makanan yang dikonsumsi selain nasi dan makanan berlemak yang dihindari. Pada hasil pemeriksaan tidak ada perbedaan ( $\mathrm{p}>0,05)$ antara kedua kelompok berdasarkan karakter usia, jenis kelamin, tingkat pendidikan, kadar glukosa darah dan porsi dalam sekali makan. Hal tersebut dapat disimpulkan bahwa data bersifat homogen.

Sementara ada perbedaan bermakna $(\mathrm{p}<0,05)$ antara kelompok intervensi dan kontrol pada karakter berdasarkan makanan yang dikonsumsi selain nasi 
(0,037). Berdasarkan Tabel 1. pada kelompok kontrol lebih banyak mengkonsumsi sayuran tanpa nasi (50\%) dibandingkan kelompok intervensi.

\section{Uji Perbandingan Hasil Pemeriksaan Awal dan Akhir Profil Lipid dan Kadar Glukosa Darah}

Hasil analisa studi diperoleh perbedaan bermakna $(\mathrm{p}<0,05)$ pada parameter kolesterol $(0,031)$ dan LDL $(0,021)$ di kelompok kontrol. Sedangkan pada kelompok intervensi, tidak ditemukan perbedaan bermakna pada semua parameter antara kedua waktu pemeriksaan.

\section{Uji Perbandingan Hasil Pemeriksaan} Awal dan Akhir Profil Lipid dan Kadar Glukosa Darah

Hasil analisa studi diperoleh perbedaan bermakna $(\mathrm{p}<0,05)$ pada parameter kolesterol $(0,031)$ dan LDL $(0,021)$ di kelompok kontrol (Tabel 2.). Sedangkan pada kelompok intervensi, tidak ditemukan perbedaan bermakna pada semua parameter antara kedua waktu pemeriksaan. Hal ini dapat disimpulkan bahwa tanpa implementasi SKEDit, kadar kolesterol dan LDL berbeda antara pemeriksaan awal dan akhir.

\section{Uji Perbandingan Hasil Pemeriksaan Akhir Profil Lipid dan Glukosa Darah}

Pada pemeriksaan akhir tidak ditemukan perbedaan pada semua parameter (profil lipid dan kadar glukosa darah ) pengukuran antara kelompok intervensi dan kontrol ( $p>0,05)$.

\section{Uji Perbandingan Hasil Pemeriksaan Akhir Profil Lipid dan Glukosa Darah}

Pada pemeriksaan akhir tidak ditemukan perbedaan pada semua parameter (profil lipid dan kadar glukosa darah ) pengukuran antara kelompok intervensi dan kontrol $(p>0,05)$.

Karakteristik Responden Penelitian ( $\mathrm{n}=20)$

\begin{tabular}{|c|c|c|c|c|c|}
\hline \multirow{2}{*}{ Indikator } & \multicolumn{2}{|c|}{ Intervensi } & \multicolumn{2}{|c|}{ Kontrol } & \multirow[b]{2}{*}{$\mathrm{p}$} \\
\hline & $\mathrm{f}$ & $\%$ & $\mathrm{f}$ & $\%$ & \\
\hline \multicolumn{6}{|l|}{ Usia (Tahun) } \\
\hline $40-55$ & 6 & 60 & 6 & 60 & \multirow{3}{*}{0,317} \\
\hline $56-65$ & 2 & 20 & 3 & 30 & \\
\hline $66-75$ & 2 & 20 & 1 & 10 & \\
\hline \multicolumn{6}{|l|}{ Jenis Kelamin } \\
\hline Pria & 4 & 40 & 5 & 50 & \multirow[t]{2}{*}{0,623} \\
\hline Wanita & 6 & 60 & 5 & 50 & \\
\hline \multicolumn{6}{|l|}{ Tingkat Pendidikan } \\
\hline Tidak Tamat Sekolah & 3 & 30 & 1 & 10 & \multirow{4}{*}{0,502} \\
\hline SD & 2 & 20 & 2 & 20 & \\
\hline SLTP & 1 & 10 & 2 & 20 & \\
\hline SLTA & 4 & 40 & 5 & 50 & \\
\hline \multicolumn{6}{|l|}{ Rata-rata presentase lemak yang dikonsumsi } \\
\hline 20-25 lemak & 0 & 0 & 1 & 10 & \multirow{3}{*}{0,05} \\
\hline 15 lemak & 0 & 0 & 5 & 50 & \\
\hline Menerka sendiri ukurannya & 10 & 100 & 4 & 40 & \\
\hline \multicolumn{6}{|l|}{ Perkiraan porsi dalam sepiring sekali makan } \\
\hline Setengah porsi piring untuk tiap kali makan besar & 7 & 70 & 5 & 50 & \multirow{3}{*}{0,511} \\
\hline Seperempat porsi piring untuk tiap kali makan besar & 2 & 20 & 5 & 50 & \\
\hline 1 porsi piring penuh nasi & 1 & 10 & 0 & 0 & \\
\hline \multicolumn{6}{|l|}{ Makanan yang dikonsumsi selain nasi } \\
\hline Roti, mie, kentang, dan lain-lain & 6 & 60 & 2 & 20 & \multirow{3}{*}{$0,037^{*}$} \\
\hline Cukup ubi saja & 3 & 30 & 3 & 30 & \\
\hline Memakan sayuran tanpa nasi & 1 & 10 & 5 & 50 & \\
\hline \multicolumn{6}{|l|}{ Makanan lemak tinggi yang dihindari } \\
\hline Daging berlemak, jeroan, kuning telur & 1 & 10 & 4 & 40 & \multirow{3}{*}{0,131} \\
\hline Es krim, sosis, cake, coklat, dendeng, makanan gorengan & 9 & 90 & 6 & 60 & \\
\hline Roti, mie, kentang & 0 & 0 & 0 & 0 & \\
\hline
\end{tabular}


Tabel 2

Uji Perbandingan Pemeriksaan Awal dan Akhir Parameter Profil Lipid dan Glukosa Darah (n=20)

\begin{tabular}{|c|c|c|c|c|}
\hline \multirow{2}{*}{ Indikator } & Awal & Akhir & \multirow{2}{*}{$\Delta$ Mean } & \multirow[b]{2}{*}{$\mathrm{p}$} \\
\hline & \multicolumn{2}{|c|}{ Mean (Min - Maks) } & & \\
\hline \multicolumn{5}{|l|}{ HDL } \\
\hline Intervensi & $33,4(24-43)$ & $41,1(25-69)$ & 7,70 & 0,063 \\
\hline Kontrol & $39,2(25-60)$ & $37,6(20-49)$ & 1,60 & 0,750 \\
\hline \multicolumn{5}{|l|}{$\mathrm{TG}$} \\
\hline Intervensi & $256,6(122-464)$ & $279,9(96-468)$ & 23,3 & 0,429 \\
\hline Kontrol & $194(72-350)$ & $242(96-392)$ & 48,0 & 0,191 \\
\hline \multicolumn{5}{|l|}{ Kol } \\
\hline Intervensi & $197,3(118-368)$ & $162,1(111-222)$ & 35,2 & 0,191 \\
\hline Kontrol & $200,7(159-299)$ & $168,1(133-228)$ & 32,6 & $0,031^{*}$ \\
\hline \multicolumn{5}{|l|}{ LDL } \\
\hline Intervensi & $113,3(90-276)$ & $87,4(65-100)$ & 25,9 & 0,128 \\
\hline Kontrol & $122,1(45-207)$ & $85,9(30-139)$ & 36,2 & $0,021 *$ \\
\hline \multicolumn{5}{|l|}{ GDS } \\
\hline Intervensi & $304,7(180-540)$ & $291(78-500)$ & 12,9 & 0,856 \\
\hline Kontrol & $248,3(120-309)$ & $261,5(99-533)$ & 13,2 & 0,673 \\
\hline
\end{tabular}

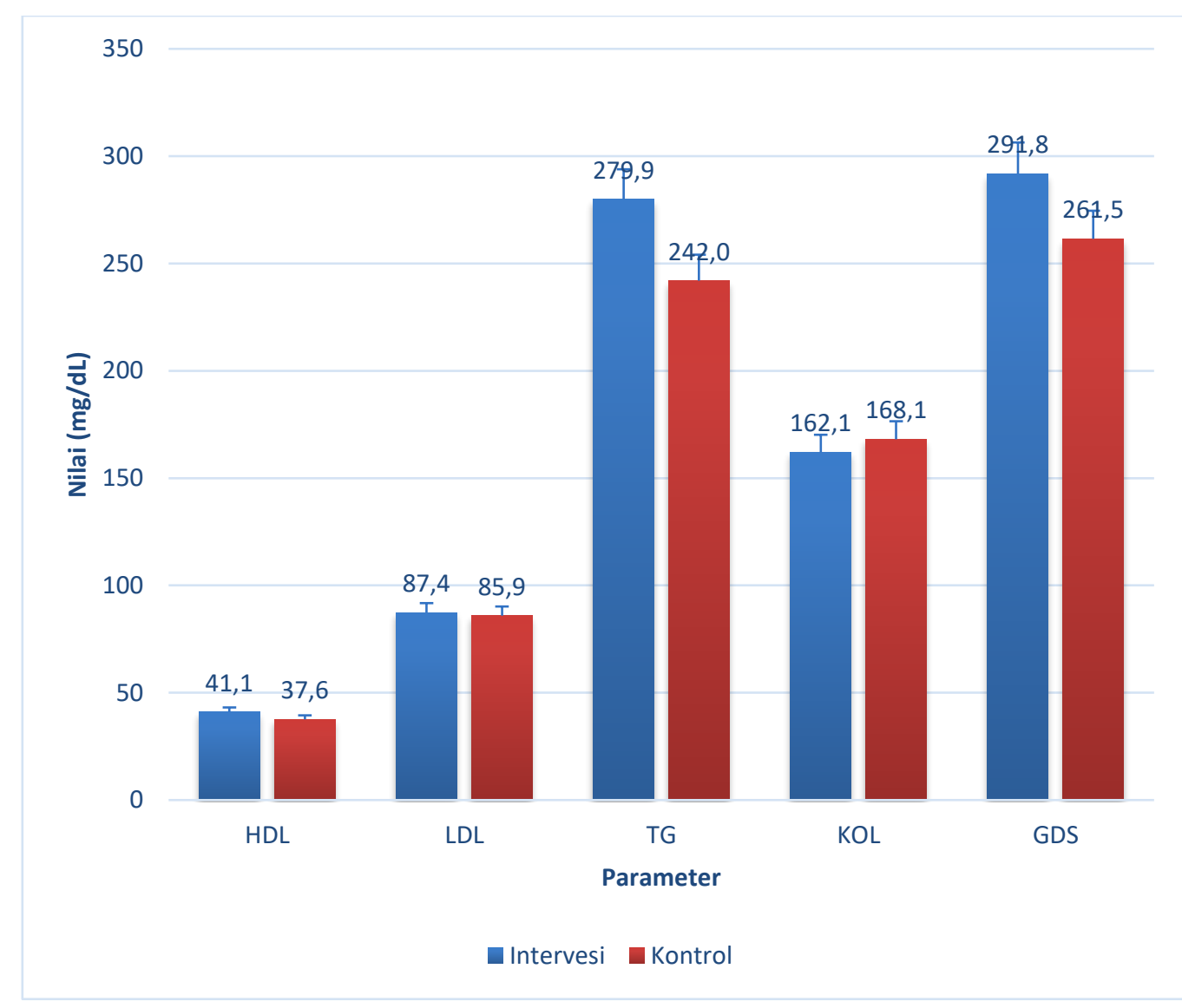

Gambar 1

Hasil Pemeriksaan Akhir Pada Profil Lipid dan Glukosa Darah 


\section{PEMBAHASAN}

\section{Efek Edukasi Diet Protein Menggunakan SKEDit terhadap Kadar Profil Lipid}

Analisis kadar profil lipid pada pemeriksaan awal dan akhir kelompok intervensi tidak ada perbedaan. Hal tersebut menunjukkan bahwa edukasi menggunakan SKEDit tidak merubah perilaku pasien untuk rutin melaksanakan diet protein dan mengontrol pola makan rendah lemak. Sementara pada kelompok kontrol terdapat perbedaan pemeriksaan awal dan akhir pada parameter Kolesterol p=0,031 dan LDL $\mathrm{p}=0,021$

$(\mathrm{p}<0,05)$. Perbedaan hasil kedua waktu tersebut didukung dengan adanya perbedaan responden pada kelompok kontrol yang mengkonsumsi lebih banyak sayur tanpa nasi (50\%) dibandingkan kelompok intervensi. Hasil studi ini sejalan dengan konsep studi yang mengkaji manfaat konsumsi sayur dalam pencegahan hiperlipidemia. Konsumsi sayur setiap hari memberikan efek hipotensif dan hipokolesterol [21]. Maka penyebab perbedaan signifikan pada profil lipid kelompok kontrol diprediksi karena responden lebih banyak konsumsi sayur.

Analisis perbedaan rata-rata kadar profil lipid antara kelompok intervensi dan kontrol menujukkan tidak ada perbedaan pada semua parameter $(p>0,05)$. Hal tersebut diduga karena faktor internal dan eksternal yang mendukung ketidakpatuhan pasien terhadap informasi yang dikirimkan secara rutin. Studi sebelumnya menjelaskan bahwa ketidakpatuhan responden terhadap informasi kesehatan bisa disebabkan oleh faktor pengetahuan, interpersonal, sikap dan variasi budaya [22]. Dari segi pengetahuan, umumnya pasien yang mendapatkan informasi kesehatan secara intensif tetap masih melupakan anjuran kesehatan saat dia pulang berobat [22]. Dalam studi ini juga menunjukkan informasi yang diberikan sudah intensif dan didukung dengan teknologi namun belum bisa memberikan hasil yang signifikan. Studi lain menjelaskan bahwa implementasi teknologi dalam edukasi kesehatan pasien akan meningkatkan kepuasan dan pemahaman dalam mencegah masalah kesehatan yang mengancam jiwa [23]. Selain itu, pasien merasakan privasi yang aman dan nyaman ketika berkonsultasi atau menerima informasi [23].

\section{Efek Edukasi Diet Protein Menggunakan SKEDit terhadap Kadar Glukosa Darah}

Analisis kadar glukosa pada kelompok kontrol dan intervensi tidak ada perbedaan antara pemeriksaan awal dan akhir ( $\mathrm{p}>$ $0,05)$. Diet protein dapat mencegah kondisi hiperglikemia karena menggantikan jumlah karbohidrat yang dikonsumsi [24]. Dengan adanya total karbohidrat yang kurang maka hal tersebut akan mengurangi glikohemoglobin minimal dalam waktu 5 minggu [24]. Hasil penelitian ini tidak sejalan dalam teori yang dijelaskan dalam konsep pencegahan hiperglikemia melalui diet protein. Hal tersebut diduga ada faktor ketidakpatuhan responden terhadap informasi yang diberikan secara rutin sehingga implementasi diet protein tidak dilaksanakan secara maksimal. Ketidakpatuhan pada pasien diabetes merupakan masalah kronis yang sudah ditemukan dalam studi terdahulu. Hal tersebut yang kemudian akan menyebabkan hasil pengobatan akhir tidak optimal [25]. Ketidakpatuhan ini juga didukung oleh faktor masalah yang kompleks seperti sering lupa dan rendahnya kemampuan literasi kesehatan [25].

Hasil uji perbandingan kadar glukosa antara kelompok kontrol dan intervensi juga tidak ada perbedaan $(\mathrm{p}>0,05)$. Hasil rata-rata usia antara kedua kelompok juga tidak ada perbedaan $(p>0,05)$. Studi serupa yang menerapkan Telehealth juga tidak menemukan perbedaan kadar glukosa darah antara kelompok intervensi dan kontrol pada pasien diabetes selama masa intervensi 2 tahun [26]. Metode Telehealth diprediksi sama efektifnya dengan cara 
tradisional yaitu melalui edukasi tatap muka [26]. Faktor usia diduga mempengaruhi hasil yang tidak berbeda pada kadar glukosa darah. Hal tersebut dapat dilihat pada usia responden masingmasing kelompok masuk ke kategori rentan mengidap diabetes ( $>30$ tahun). Pada usia 31 -45 tahun penderita diabetes juga sudah rentan menderita komplikasi kronis seperti retinopati $[27,28]$.

Studi ini masih terdapat kelemahan yaitu tidak dilakukan pengkajian ulang pengetahuan responden kelompok yang menjalani intervensi. Faktor pengetahuan dijelaskan dalam studi sebelumnya mempengaruhi kepatuhan responden terhadap informasi edukasi kesehatan yang disampaikan baik secara daring maupun tatap muka.

\section{SIMPULAN}

Implementasi Telehealth menggunakan SKEDit bisa menjadi rekomendasi yang efektif untuk mendukung metode edukasi kesehatan namun perlu didukung dengan kepatuhan pasien yang baik. Pengkajian tingkat pengetahuan awal dan akhir pada responden juga diperlukan untuk mengetahui kepatuhan terhadap edukasi kesehatan yang diberikan khususnya pada penderita diabetes. Dengan demikian, maka terapi pemulihan pasien diabetes dapat dilaksanakan optimal.

\section{UCAPAN TERIMAKASIH}

Ucapan terima kasih disampaikan kepada Kementerian Pendidikan dan Kebudayaan (Kemdikbud) yang telah memberikan bantuan dana hibah sehingga penelitian ini dapat terlaksana. Ucapan terima kasih juga disampaikan kepada Klinik Kitamura Pontianak yang memberikan ruang kepada peneliti untuk melakukan penelitian. Penelitian ini juga didukung oleh bantuan Rovi Yana, Delvi Maiza dan Raden Taufiq Septiyo Noegroho yang bertugas sebagai asisten penelitian.

\section{REFERENSI}

[1] Saeedi P, Petersohn I, Salpea P, Malanda B, Karuranga S, Unwin N, et al. Global and regional diabetes prevalence estimates for 2019 and projections for 2030 and 2045: Results from the International Diabetes Federation Diabetes Atlas, $9^{\text {th }}$ edition. Diabetes Res Clin Pract 2019;157.

https://doi.org/10.1016/j.diabres.2019.10784 3.

[2] International Diabetes Federation I. IDF Diabetes Atlas Update. 2015.

[3] Sheleme T, Mamo G, Melaku T, Sahilu T. Prevalence, patterns and predictors of chronic complications of diabetes mellitus at a large referral hospital in Ethiopia: A prospective observational study. Diabetes, Metab Syndr Obes Targets Ther 2020;13:4909-18. https://doi.org/10.2147/DMSO.S281992.

[4] Kosiborod M, Gomes MB, Nicolucci A, Pocock S, Rathmann W, Shestakova M V, et al. Vascular complications in patients with type 2 diabetes: prevalence and associated factors in 38 countries (the DISCOVER study program). Cardiovasc Diabetol 2018;17:150. https://doi.org/10.1186/s12933-018-0787-8.

[5] Aastha Chawla, Rajeev Chawla SJ. Microvasular and macrovascular complications in diabetes mellitus: Distinct or continuum? Indian J Endocrinol Metab 2016;20. https://doi.org/10.4103/2230-8210.183480.

[6] Barot M, Gokulgandhi MR, Patel S, Mitra AK. Microvascular complications and diabetic retinopathy: recent advances and future implications. Future Med Chem 2013;5:301-14. https://doi.org/10.4155/fmc.12.206.

[7] Association AD. Diagnosis and classification of diabetes mellitus. Diabetes Care 2009;32 Suppl 1:S62-7. https://doi.org/10.2337/dc09-S062.

[8] Chakrabarti P, Kim JY, Singh M, Shin Y-K, Kim J, Kumbrink J, et al. Insulin inhibits lipolysis in adipocytes via the evolutionarily conserved mTORC1-Egr1-ATGL-mediated pathway. Mol Cell Biol 2013;33:3659-66. https://doi.org/10.1128/MCB.01584-12.

[9] Guilherme A, Virbasius J V, Puri V, Czech MP. Adipocyte dysfunctions linking obesity to insulin resistance and type 2 diabetes. Nat Rev Mol Cell Biol 2008;9:367-77. https://doi.org/10.1038/nrm2391.

[10] Marshall JA, Bessesen DH. Dietary Fat and the Development of Type 2 Diabetes. Diabetes Care 2002;25:620 LP - 622. https://doi.org/10.2337/diacare.25.3.620.

[11] Rhee E-J, Kim HC, Kim JH, Lee EY, Kim BJ, Kim EM, et al. 2018 Guidelines for the management 
of dyslipidemia. Korean J Intern Med 2019;34:723-71.

https://doi.org/10.3904/kjim.2019.188.

[12] Ke Q, Chen C, He F, Ye Y, Bai X, Cai L, et al. Association between dietary protein intake and type 2 diabetes varies by dietary pattern. Diabetol Metab Syndr 2018;10:48. https://doi.org/10.1186/s13098-018-0350-5.

[13] Lacroix M, Gaudichon C, Martin A, Morens C, Mathé $\mathrm{V}$, Tomé $\mathrm{D}$, et al. A long-term high-protein diet markedly reduces adipose tissue without major side effects in Wistar male rats. Am J Physiol Regul Integr Comp Physiol 2004;287:R934-42.

https://doi.org/10.1152/ajpregu.00100.2004.

[14] Lee K, Jin H, Chei S, Lee J-Y, Oh H-J, Lee B-Y. Dietary Silk Peptide Prevents High-Fat DietInduced Obesity and Promotes Adipose Browning by Activating AMP-Activated Protein Kinase in Mice. Nutrients 2020;12:201. https://doi.org/10.3390/nu12010201.

[15] Zhao W-T, Luo Y, Zhang Y, Zhou Y, Zhao T-T. High protein diet is of benefit for patients with type 2 diabetes: An updated meta-analysis. Medicine (Baltimore) 2018;97:e13149. https://doi.org/10.1097/MD.0000000000013 149.

[16] Hamdy O, Horton ES. Protein content in diabetes nutrition plan. Curr Diab Rep 2011;11:111-9.

https://doi.org/10.1007/s11892-010-0171-X.

[17] Posthauer ME, Banks M, Dorner B, Schols JMGA. The role of nutrition for pressure ulcer management: national pressure ulcer advisory panel, European pressure ulcer advisory panel, and pan pacific pressure injury alliance white paper. Adv Skin Wound Care 2015;28:175-90. https://doi.org/10.1097/01.ASW.0000461911 .31139.62.

[18] Wang X, Son M, Meram C, Wu J. Mechanism and Potential of Egg Consumption and Egg Bioactive Components on Type-2 Diabetes. Nutrients 2019;11:357. https://doi.org/10.3390/nu11020357.

[19] Klonoff DC. Using telemedicine to improve outcomes in diabetes--an emerging technology. J Diabetes Sci Technol 2009;3:624-8. https://doi.org/10.1177/1932296809003004 01.

[20] Andodo C, Haryanti F, Widyandana W.
Telenursing Using SKEDit To Educate Parents with Thalassemia Children. J Keperawatan Soedirman; Vol 14, No 32019.

[21] Adebawo O, Salau B, Ezima E, Oyefuga O, Ajani E, Idowu $G$, et al. Fruits and vegetables moderate lipid cardiovascular risk factor in hypertensive patients. Lipids Health Dis 2006;5:14. https://doi.org/10.1186/1476511X-5-14.

[22] Martin LR, Williams SL, Haskard KB, Dimatteo MR. The challenge of patient adherence. Ther Clin Risk Manag 2005;1:189-99.

[23] Jeganathan S, Prasannan L, Blitz MJ, Vohra N, Rochelson B, Meirowitz N. Adherence and acceptability of telehealth appointments for high-risk obstetrical patients during the coronavirus disease 2019 pandemic. Am J Obstet Gynecol MFM 2020;2:100233. https://doi.org/10.1016/j.ajogmf.2020.10023 3.

[24] Gannon MC, Nuttall FQ. Effect of a High-Protein, Low-Carbohydrate Diet on Blood Glucose Control in People With Type 2 Diabetes. Diabetes 2004;53:2375 LP - 2382. https://doi.org/10.2337/diabetes.53.9.2375.

[25] Conway CM, Kelechi TJ. Digital Health for Medication Adherence in Adult Diabetes or Hypertension: An Integrative Review. JMIR Diabetes 2017;2:e20-e20. https://doi.org/10.2196/diabetes.8030.

[26] Ciemins E, Coon P, Peck R, Holloway B, Min S-J. Using telehealth to provide diabetes care to patients in rural Montana: findings from the promoting realistic individual self-management program. Telemed J E Health 2011;17:596-602. https://doi.org/10.1089/tmj.2011.0028.

[27] Sattar N, Rawshani A, Franzén S, Rawshani A, Svensson A-M, Rosengren A, et al. Age at Diagnosis of Type 2 Diabetes Mellitus and Associations With Cardiovascular and Mortality Risks. Circulation 2019;139:2228-37. https://doi.org/10.1161/CIRCULATIONAHA.1 18.037885 .

[28] Zou W, Ni L, Lu Q, Zou C, Zhao M, Xu X, et al. Diabetes Onset at 31-45 Years of Age is Associated with an Increased Risk of Diabetic Retinopathy in Type 2 Diabetes. Sci Rep 2016;6:38113. https://doi.org/10.1038/srep38113. 